\title{
Delineation of iron and manganese status in soils of central research station Akola
}

'BURLA SRIHARI RAO, ${ }^{2}$ D. B. PATIL, ${ }^{3}$ MOHANA RAO PULI AND ${ }^{4}$ JAYALAKSHMI M

${ }^{1,3} \&^{4}$ PG Students, Department of Soil Science and Agricultural Chemistry, Dr. PDKV Akola

${ }^{2}$ Associate Professor and Jr. Soil Scientist, Department of SSAC, Dr. PDKV, Akola.

Received: $\quad 13.10 .14$

Accepted: $\quad 10.02 .15$

\section{ABSTRACT}

A study of delineation of Iron (Fe) and Manganese (Mn) status in soils of Central Research station, Akola was conducted during the year 2006 and 2007. Detailed maps of micronutrient also prepared. Delineation of study area was completed with help of global positioning system and for predicting available cationic micronutrient status extraction with chelating agent such as di ethylene triamine penta acetic acid (DTPA) is used. The soils of Central Research Station were found 20 per cent deficient in iron and 7 per cent deficient in manganese. While the available micronutrient status of Central Research Station soils was found as iron 0.12 to 16.32 and manganese 0.32 to 16.78 .

Key words: Delineation, Iron and Manganese.

Iron and manganese are categorized as Micronutrient, have also been called minor or trace elements, indicating that their concentrations in plant tissues are minor or in trace amounts relative to the macronutrients (Mortvedt, 2000). Available iron in Indian soils greatly varies from traces to 386 ppm. The variation is mainly attributed to the soil types and their characteristics nature of chemical extractants used and agro ecological conditions (Singh and Sekhon, 1991, Sangwan and Singh 1993, Bhogal 1993, Rajkumar et al., 1990).

The role of $\mathrm{Fe}$ in plant metabolism was recognized after the observation by Gris in 1844 that $\mathrm{Fe}$ was necessary for the maintenance of chlorophyll in plants. Iron is an essential component of many enzymes and carriers such as catalase, peroxidase, cytochrome and ferredoxin and performs an essential role in nuclic acid metabolism.

The essentiality of $\mathrm{Mn}$ in plant nutrition was established by McHargue in 1992. Manganese exists on $\mathrm{Mn}^{+2}$ in plant cell in various complexed states and can form metallo proteins. It is tightly bound in chloroplast. Though, manganese average concentration in the plant cell is about $100 \mathrm{ppm}$ it plays an important role in several biochemical processes in plants (Agrawal and Sharma 1979). It's most critical role in green plants is in light dependent water splitting reaction and oxygen evolution during photosynthesis. Manganese enhances assimilation of carbon dioxide and sugar in plants. It also plays a role in the synthesis of secondary metabolites, is involved in shikimic acid pathway (Burnell, 1988) and enhances the resistance of plants to diseases. Manganese supply retards the rate of electron transport and IAA oxidase activity for root nodulation.

Keeping this in a view a systematic study, including assessment of nutrient status of different soils with delineation of areas of Iron and Manganese deficiency and/or sufficiency was started.

\section{MATERIALS AND METHODS}

In view of the emerging micronutrient deficiencies in soils and plants, a systemic approach for assessment of micronutrient status of soils of eight blocks of central Research station, Dr. Panjabrao Deshmukh Krishi Vidyapeeth, Akola. was employed which comprising soil sampling, their analysis and delineation of $\mathrm{Fe}$ and $\mathrm{Mn}$ deficient areas. Total 222 surface soil $(0-30 \mathrm{~cm})$ geo referenced samples from central Research station with latitude and longitude using global positioning system (GPS) were collected and soil variability were analyzed for DTPA extractable Fe and Mn.

The central research station is situated about 2 $\mathrm{km}$ east of Akola town. It is located at longitude $77^{0}$ $02^{1} 44^{1 \mathrm{ll}}$ to $77^{0} 04^{1} 59^{11} \mathrm{E}$, Latitude $20^{0} 42^{1} 15^{11}$ to $20^{0}$ $43^{1} 18^{\mathrm{ll}} \mathrm{N}$. The research station extends over an area of 1145 hectares. Akola town is accessible both by road NH No. 6 and rail Nagpur Mumbai, central Railway. The farm area is bounded by Gudadhi and Akola- Borgaon Manju road in the north, Sivani village in the south, Babhulgaon in the east and Umri in the west.

Mechanical analysis was done by using Bouyoucos hydrometer method (Bouyoucos, 1928), Soil pH (1:2.5) and Ec were estimated By using pH meter and Electrical Conductivity meter respectively (Jackson, 1967) and Available Fe and Mn were determined by using DTPA (Diethylene triamine penta acetic acid) extract on AAS (Lindsay and Norvell,1978).

Maps for soil sampling sites were generated using map send worldwide, Thales Navigation system. 
Journal of Progressive Agriculture Vol. 6, Issue-1, April, 2015

Table 1. Important soil characteristics of CRS Akola.

\begin{tabular}{lcccccc}
\hline \multicolumn{1}{c}{ Block } & $\mathbf{p H}$ & $\mathbf{E C}\left(\mathbf{d S m}^{-1}\right)$ & \multicolumn{3}{c}{ Texture } \\
\cline { 3 - 6 } & & & Sand \% & Silt \% & Clay \% & Textural Class \\
\hline Mission school & $7.8-8.6$ & $0.18-0.36$ & 20 & 13 & 67 & Clay \\
Malkapur & $7.6-8.8$ & $0.28-0.36$ & 21 & 23 & 56 & Clay \\
Shivar & $7.8-8.6$ & $0.22-0.38$ & 34 & 21 & 45 & Clay loam \\
Western & $7.6-8.8$ & $0.24-0.44$ & 35 & 25 & 40 & Silty clay \\
Shivani & $7.8-8.7$ & $0.23-0.49$ & 53 & 12 & 35 & Clay loam \\
Gudadi & $7.7-8.4$ & $0.24-0.49$ & 23 & 33 & 44 & Silty clay \\
Babulgaon & $7.6-8.5$ & $0.22-0.68$ & 25 & 23 & 52 & Clay \\
High way & $7.9-8.7$ & $0.20-0.58$ & 19 & 26 & 55 & Clay \\
\hline
\end{tabular}

Table 2: Available iron status of CRS soils

\begin{tabular}{lccc}
\hline \multicolumn{1}{c}{ Blocks } & No. of samples analyzed & Available range $\left(\mathbf{m g ~} \mathbf{~ k g}^{-\mathbf{1}}\right)$ & $\left.\mathbf{M e a n}_{\mathbf{( m g}} \mathbf{~ k g}^{-\mathbf{1}}\right)$ \\
\hline Mission School & 21 & $0.12-7.85$ & 5.31 \\
Malkapur & 27 & $0.38-8.96$ & 5.77 \\
Shivar & 30 & $4.66-16.32$ & 7.29 \\
Western & 22 & $3.75-14.64$ & 6.38 \\
Shivani & 44 & $2.0-9.4$ & 6.07 \\
Gudadhi & 32 & $2.40-8.30$ & 4.78 \\
Babulgaon & 31 & $3.48-8.22$ & 4.92 \\
High way & 15 & $3.84-8.99$ & 5.93 \\
Total & 222 & $0.12-16.32$ & 5.81 \\
\hline
\end{tabular}

Table 3: Available iron status of CRS soils (DTPA extracts)

\begin{tabular}{lllll}
\hline Blocks & No. of samples analyzed & Low $<\mathbf{4 . 5} \mathbf{~ m g ~ k g}^{-1}$ & Medium 4.5 to $\mathbf{7 . 5} \mathbf{~ m g ~ k}^{-1}$ & High $>\mathbf{7 . 5 ~} \mathbf{~ m g ~ k g}^{-1}$ \\
\hline Mission School & 21 & $2(10 \%)$ & $18(81 \%)$ & $2(9 \%)$ \\
Malkapur & 27 & $3(11 \%)$ & $15(59 \%)$ & $9(30 \%)$ \\
Shivar & 30 & $0(0 \%)$ & $17(57 \%)$ & $13(43 \%)$ \\
Western & 22 & $1(4 \%)$ & $14(64 \%)$ & $7(32 \%)$ \\
Shivani & 44 & $2(5 \%)$ & $34(77 \%)$ & $8(16 \%)$ \\
Gudadhi & 32 & $15(47 \%)$ & $15(47 \%)$ & $2(6 \%)$ \\
Babulgaon & 31 & $19(41 \%)$ & $10(32 \%)$ & $2(6 \%)$ \\
High way & 15 & $3(20 \%)$ & $9(60 \%)$ & $3(20 \%)$ \\
Total & 222 & $45(20 \%)$ & $132(60 \%)$ & $45(20 \%)$ \\
\hline
\end{tabular}

Table 4: Available manganese status of Central Research Station soils

\begin{tabular}{lccc}
\hline \multicolumn{1}{c}{ Blocks } & No. of samples analyzed & Available range $\left(\mathbf{m g ~} \mathbf{~ k g}^{-\mathbf{1}}\right)$ & $\left.\mathbf{M e a n ~}_{\mathbf{( m g}} \mathbf{~ k g}^{-\mathbf{1}}\right)$ \\
\hline Mission School & 21 & $0.72-7.05$ & 4.61 \\
Malkapur & 27 & $1.64-4.67$ & 3.79 \\
Shivar & 30 & $3.51-16.78$ & 5.86 \\
Western & 22 & $1.79-16.17$ & 4.59 \\
Shivini & 44 & $1.79-6.04$ & 4.40 \\
Gudadhi & 32 & $0.32-9.43$ & 3.33 \\
Babulgaon & 31 & $2.83-8.88$ & 4.91 \\
High way & 15 & $2.95-8.33$ & 5.74 \\
Total & 222 & $0.32-16.17$ & 4.65 \\
\hline
\end{tabular}


Table 5: Available manganese status of central research station soils (DTPA Extractable)

\begin{tabular}{lcccc}
\hline \multicolumn{1}{c}{ Blocks } & No. of samples analyzed & Low $<\mathbf{2 . 0} \mathbf{~ m g ~ k g}$ & Medium $\mathbf{2 . 0}$ to 4.0 $\mathbf{~ m g ~ k g}^{-\mathbf{1}}$ & $\mathbf{H i g h}^{\mathbf{1}} \mathbf{4 . 0} \mathbf{~ m g ~ k g}$ \\
\hline Mission School & 21 & $2(10 \%)$ & $4(19 \%)$ & $15(71 \%)$ \\
Malkapur & 27 & $1(4 \%)$ & $12(44)$ & $14(52 \%)$ \\
Shivar & 30 & $0(0 \%)$ & $6(20 \%)$ & $24(80 \%)$ \\
Western & 22 & $2(9 \%)$ & $9(41 \%)$ & $11(50 \%)$ \\
Shivini & 44 & $4(9 \%)$ & $7(16 \%)$ & $33(75 \%)$ \\
Gudadhi & 32 & $8(25 \%)$ & $14(44 \%)$ & $10(31 \%)$ \\
Babulgaon & 31 & $0(0 \%)$ & $8(29 \%)$ & $23(71 \%)$ \\
High way & 15 & $0(0 \%)$ & $3(20 \%)$ & $12(80 \%)$ \\
Total & 222 & $17(7 \%)$ & $63(29 \%)$ & $42(64 \%)$ \\
\hline
\end{tabular}

(Figures in parenthesis indicates percentage of sample size)

\section{RESULTS AND DISCUSSION}

\section{Soil of study area:}

It was observed (Table 1) that soil $\mathrm{pH}$ varied from 7.6 to 8.8 with an average of 8.1. According to classification of soil reaction suggested by Brady (1985) samples were found moderately alkaline to strongly alkaline. The minimum value of $\mathrm{pH} 7.6$ was observed in Malkapur western and Babhulgaon Soils and maximum value of $\mathrm{pH} 8.8$ was observed in soil of Malkapur and Western Block.

The electrical conductivity of the soils varied from 0.18 to $0.68 \mathrm{~d} \mathrm{~S} \mathrm{~m}^{-1}$. On the basis of the limits suggested by Muhr et al.,(1963) for judging salt problem of soils, most of samples were found normal $\left(\mathrm{EC}<1.0 \mathrm{dSm}^{-1}\right)$. The soil texture varied from clay to clay loam and silty clay.

\section{Available iron status of CRS soils}

The various forms of iron in soil are the immediately available, the available pool, available on decomposition and potential medium long term sources of available iron (Katyal and Deb, 1982). The plant usable fraction of soil iron can be determined by employing a suitable chemical extractant and its critical concentration in soil can be established by correlating with crop yield.

The available iron content varies from 0.12 to $16.32 \mathrm{mg} \mathrm{kg}^{-1}$ with a mean of $5.81 \mathrm{mg} \mathrm{kg}^{-1}$ (Table 2) regards iron status of central research station soils, $20 \%$ soil samples are low, 60\% samples medium and $20 \%$, soil samples are high in available iron out of 222 soil samples (Table 2 and Fig 1). The iron deficiency was observed except Shivar soil 10 per cent in mission school, 11 per cent Malkapur, 4 per cent in western, 5 per cent in Shivani, 47\% in Gudadhi, 61 per cent in Babulgaon and 20 per cent in High way Block soil.

In spite of high total iron in soils, its availability to the crops is a major problem in many soils. Usually crops take up iron as $\mathrm{Fe}^{+2}$ and in available soils $\mathrm{Fe}^{+2}$ oxidizes to the unavailable $\mathrm{Fe}^{+3}$ form. Soil with $\mathrm{pH} 7$ is the major factor which governs the solubility and an increase in $\mathrm{pH}$ decreases solubility of divalent and trivalent cation by $100-1000$ folds respectively.

Fine texture soil retained major part of applied iron in unavailable form because of surface adsorption and only small fraction was made available (Table 1 and 2).

\section{Available Manganese status of CRS soils}

Available Mn constitutes $1-15 \%$ of the total soil $\mathrm{Mn}$, the size of which with climatic conditions, soil type and extraction method used.

The behaviour of Mn in soils depends largely on $\mathrm{pH}$ and redox potential. All factors which influence oxidation reduction influence $\mathrm{Mn}$ solubility and its availability to plants. These include $\mathrm{pH}, \mathrm{CaCO}_{3}$, organic matter, microbial activity and soil moisture. A rise in $\mathrm{pH}$, increases oxidation of $\mathrm{Mn}$, whether the process is chemical or biological and thus at high $\mathrm{pH}, \mathrm{Mn}$ availability to plants is reduced. The reverse is true in acid soils. The soluble $\mathrm{Mn}^{+2}$ decreases 100 fold for each unit increase in $\mathrm{pH}$ which also enhances the formation of $\mathrm{Mn}$ - Soil organic matter complexes which also render Mn less available (Page 1962).

Available Mn was extracted by DTPA from 222 soil samples collected from central research station farm and the content varied between 0.32 to $16.17 \mathrm{mg} \mathrm{kg}^{-1}$ with the mean of $4.65 \mathrm{mg} \mathrm{kg}^{-1}$ (Table 4) Based on critical limits, availability of Mn would be rated as marginal to adequate in soils of Central Research Station. Out of total samples 7 per cent soil samples are in low, 29 per cent in medium and 64 per cent soil samples in high range in available Mn. (Table 5 and Fig. 2) Thus, at present a positive response to $\mathrm{Mn}$ application is unlikely due to its adequacy in majority of soils. 


\section{REFERENCES}

Agarwala, S.C. and Sharma, C.P. (1979). Recognizing micronutrients Disorders in crop plants on the Basis of visible symptoms and plant analysis, Lucknow Univ, Lucknow. India. PP:72.

Bhogal, N. S. (1993). Micronutrient status in aqhic ustifluvents and udifluvents on related to certain soil properties. J. Indian Soc. Soil Sci. 41: $75-78$.

Brady, N. C. (1985). The nature and properties of soils, $8^{\text {th }}$ Edition. Macmillan publishing co. inc. New york.

Burnell, J.N. (1988). The biochemistry of manganese in plants. In proc. Intern. Symp. On manganese in soil and plants. Kluwar Acad. Pub. Dordrecht. 3-4.

Gris, E. (1844). Nouvelles experience sur I action des composes ferrugeneux solubles, et de la debilite des plants. G. R. Acad, Sci. (Paris) 19: 1118-1119.

Jackson, M.L. (1967). Studies on physico chemical properties of soil from Jayakwadi commond area, J. Maharashtra Agri. Univ. 4(1): 97-98.

Katyal, J.C. and Deb, D.L. (1982). Nutrient transformation in soils micronutrients in review of soil research in India, Part.- I. Indain Soc. Soil. Sci. New Delhi 12: 146-159.

Lindsay, W.L. and Norvell, W.A. (1978). Development of DTPA micronutrient soil test, Agronomy Abstract. 84.
McHargue, J. S. (1922). Role of manganese in plants. J. Amer. Chem.Soc. 44: 1592-1598.

Mortvedt, J.J. (2000). Bio availability of micronutrients in "Handbook of soil Science" (M.E. Summer, Ed), PP D 71-D88. CRC Press, Boca Raton, FL

Muhr, G.R., Dutta, N.P., Subraney, N., Dever, F. Lacy. V.K. and Donahue, R.R. (1963). Soil Testing in India, USAID Mission to India.

Page E. R. (1962). Studies on soil and plant manganese II the relationship of soil $\mathrm{pH}$ to manganese availability. Plant and Soil, 16: 247-257.

Rajkumar, Nayyar, V.K., Sidhu, M.S. and Deshmukh, S. N. (1990) : Distribution of available micronutrients cations in some dominent soil series in differnt tphyvographic units of Bundelkhand Region of Madhya Pradesh, J. Indian Soc. Soil Sci. 38 (3) : 410415.

Sangwan, B.S. and Singh, K. (1993). Varietal distribution of $\mathrm{Zn}, \mathrm{Mn}, \mathrm{Cu}$ and $\mathrm{Fe}$, in the semi arid of Haryana and their relations with soil properties. J. Indian Soc. Soil Science, 41: 463-467.

Singh, M. and Sekhon G.S. (1991). DTPA extratable micronutrient cations in twenty soil series of India. J. Indian Soc. Soil Sci. 38: $129-133$. 